\title{
The Power of Materialist-Environmental Explanations: General and Specific Evolution, and the Incest Taboo
}

\author{
Gregory C. Leavitt \\ Retired, Idaho State University, Pocatello, USA \\ Email: leavgreg@isu.edu
}

How to cite this paper: Leavitt, G. C. (2021). The Power of Materialist-Environmental Explanations: General and Specific Evolution, and the Incest Taboo. Sociology Mind, 11, 81-94.

https://doi.org/10.4236/sm.2021.113007

Received: April 21, 2021

Accepted: July 4, 2021

Published: July 7, 2021

Copyright $\odot 2021$ by author(s) and Scientific Research Publishing Inc. This work is licensed under the Creative Commons Attribution International License (CC BY 4.0).

http://creativecommons.org/licenses/by/4.0/

\section{(c) (i) Open Access}

\begin{abstract}
The incest taboo has been the subject of much curiosity since the mid-19 $9^{\text {th }}$ century. While the taboo and its violation have consumed much attention especially concerning the abuse of children, other scholars have focused on the origin of the incest taboo. This focus on origin created a division between those who ascribed to Darwin's selection theory and those who recognized environmental conditions. In the latter case what has been underdeveloped is an understanding of materialist-environmental theory as a powerful explanation for understanding complex human behaviors. In the following article I will examine the nature of materialist-environmentalism and its efficacy in explaining sociocultural evolution of human society, the specific evolution of the Hindu taboo against eating beef, and the general sociocultural evolution of the incest taboo, as powerful examples of material-environmental theory. In conclusion I will survey specifically the origin of the incest taboo through environmental theory.
\end{abstract}

\section{Keywords}

Incest Taboo, Darwinian Selection Theory, Materialist-Environmental Theory, General and Specific Sociocultural Evolution

[Socioculture] is the name of a distinct order, or class, of phenomena... The [sociocultural system] can be described and interpreted in terms of principles and laws of its own (White, 1949: p. 364, 363). ${ }^{1}$

\section{Introduction}

The incest taboo has been, and is, the subject of much comment in the litera${ }^{1}$ While Leslie White ([1949]1969: p. 364) and Marvin Harris (1979) use the term "culture." I use the more modern reference "socioculture," which is the contraction of the terms society and culture. 
tures of cultural anthropology, sociology, psychology and evolutionary biology. In the $19^{\text {th }}$ century there began an intense debate within and between these disciplines on the origin of the taboo. Edward Tylor (1888), an anthropologist, put forth an environmental explanation while Edward Westermarck (1891), referring to Charles Darwin's selection theory, proposed an evolutionary account of the incest taboo. By the $20^{\text {th }}$ century the disciplinary lines in this debate were becoming more pronounced with cultural anthropology and sociology proposing environmental theories and evolutionary biology and psychology asserting a Darwinian model as the chief rival to environmental models.

In 1975, with the publication of Sociobiology, Edward O. Wilson purported that materialist-environmental explanations in the social sciences were all but dead and would be replaced by a Darwinian social science scheme. This proposed that complex human behaviors could be explained by modern selection theory. As sociobiology developed and spread, the incest taboo was asserted to be the best example of a naturally selected complex behavior because the taboo is universal; that is, sociobiology claims that universality indicates that a complex behavioral trait has a biological foundation. This proposal was readily accepted not only in evolutionary biology but also in biological anthropology and evolutionary psychology.

The acceptance of selection theory for explaining the incest taboo is in large part due to the high status of the modern Darwinian synthetic theory in the biological sciences, and in science more generally. Few today would challenge the explanatory authority of natural selection for explaining the changes in biological organisms. However, its extension to complex human behavior surpasses the phenomenon that selection theory is developed to explain. As White notes above, sociocultural phenomenon, or complex human behavior, is governed by its own laws and principles. As such, it is not a phenomenon that lends itself to selection theory. Modern Darwinian Theory is based on the premise that evolutionary changes occur one gene mutation at a time. This makes it difficult to explain complex biological organisms as well as complex human behavior like incest avoidance (Denton, 1985; Leavitt, 2005: pp. 49-84).

In this article I will argue that materialist-environmental theory provides a powerful explanation that can more easily and simply explain complex sociocultural phenomena like incest avoidance and the incest taboo. In doing this, I will examine the historical development of the environmental model, its basic structure and components, as well as sociocultural general and specific evolution. In the end, we will see that the incest taboo is a strong sociocultural rule, with its strength coming from religion, science, and harsh condemnation when violated. As acknowledged in the early social science literature, why would such a rule exist if incest is avoided by an inherent mechanism (White [1949]1969: p. 309)?

\section{Materialist-Environmental Theory}

Materialism is a theoretical paradigm common to empirical disciplines. This in- 
cludes the philosophy of science and all of the practicing sciences. Fundamental to this paradigm is the assumption that reality can be known through the five human senses, and that these observations can be measured for the purpose of uncovering universal laws and developing concepts that accurately reflect this reality. In this regard, Harris (1979: p. 27) proposes that "[sociocultural] materialism shares with other scientific strategies an epistemology which seeks to restrict fields of inquiry to events, entities, and relationships that are knowable by means of explicit, logico-empirical, inductive-deductive, quantifiable public procedures or 'operations' subject to replication by independent observers."

Difficulty arises because the natural sciences deal exclusively with physical phenomena, whereas the social sciences also regard human behavior, its organization, and its ideas as observable reality subject to the scientific method. While natural science may in some sense accept the existence of social facts, they also question whether these social things are subject to natural law or are observable as part of nature per se. Rather, these sociocultural things are seen by the natural sciences as human creations subject to human volition and thus divorced from the scientific method.

This conclusion not only defies the assumptions of materialism and science but places the human being as something unique in the universe; that is, everything in the universe is subject to natural law except for humanity. This kind of exceptionalism has been most common in the humanities and religion but we also see it in the natural sciences. As I proceed, I will demonstrate that social science can be a science with all its trappings, strengths and foibles. In fact, I will demonstrate "that human life is a response to the practical problems of earthly existence” (Harris, 1979: p. ix).

Materialist-environmentalism proposes that complex human behavior is totally subject to forces in the environment: This premise is the foundation of materialist-environmental theory (Elwell, 2013: p. 1). The environment comprises the natural environment including most importantly the climate and available resources. But the environment also includes the human milieu and its important traits as discussed below. This theoretical proposal does not include environmental determinism in the sense that particular environments always produce the same result, but more often will produce statistically similar results. This we will see with regards to the incest taboo as with other sociocultural traits.

The most important parts of the human environment for understanding sociocultural behavior are the natural environment, technology, and the techniques of its use. This premise was first offered by Karl Marx (1867: p. 406): “Technology discloses man's mode of dealing with Nature, the process of production by which he sustains his life, and thereby lays bare the mode of formation of his social relations, and the mental conception that flow from them." More specifically is the importance of subsistence technology, as it has often been used to represent the type of society, and the type of society subsequently reveals many of society's characteristics and behaviors. For example, the bow and arrow and 
digging stick characterize hunting and gathering society as the steam engine characterizes industrial people (see Lenski, 1970).

Leslie White ([1949]1969: p. 365), following Marx, said that the technological system is "primary and basic in importance" for understanding the behavior and thought in sociocultural systems. White goes forward and defines these other two primary systems. The social system is composed of all human relationships from the immediate family to large bureaucracies. Important social systems include the family, the economic and political systems, and the religious institution. As suggested by Marx, the technology system, which develops initially for human adaptation to the natural environment, largely shapes the social systems that make up society. As technology develops becoming more complex so too does the social system. This is witnessed in increasingly complex organizations and in increasingly complex social stratification and social differentiation.

The third system is the ideological system. The term "ideology" is used by White to represent all human thought; ideas and beliefs as well as mythologies, philosophies, religious beliefs, and a peoples' world view. Technology and the social systems largely shape the ideology of society (Leavitt, 1986: pp. 525-553). As White points out, the impact of one system on the other systems does not run in one causal direction. For example, once the social system is established it can shape the technological system: the educational system may have a significant impact on the development of technology though the technological system generally will set the context in which tools develop. In other words, the social system of an advanced agriculture society is not going to inspire the development of a space shuttle but it may develop a more sophisticated plow. Likewise, the ideological system may have some effect on the other two systems. For example, the ideology of democracy leads to the development of political parties and the development of voting technologies.

The modern materialist-environmental theory in social science has been developed by Marvin Harris ([1968]2001, 1974, 1979). While he followed the lead of others, Harris went the farthest in developing an environmental theoretical structure and applying it to a wide range of phenomenon. Harris' most noted theoretical contribution was his expansion of the technological system calling it the "infrastructure." Although he never defined infrastructure clearly in one place a reading of his works leads to the conceptualization offered below. ${ }^{2}$

Harris described infrastructure as the modes of production and reproduction (Harris, 1979: pp. 52-53). The mode of production is comprised of the technology of subsistence, techno-patterns environmental relationships, the ecosystem and work. The mode of reproduction is comprised of demography, mating patterns; fertility; natality, mortality, nurturance of infants, medical control of demographic patterns and contraception, abortion, and infanticide. Some have claimed that Harris included "economic factors" (Buzney \& Marcoux, 2021) in ${ }^{2}$ Harris (1979: pp. 51-54) divides each sociocultural system into etic and emic modes. I list only the etic characteristics of each system, or the observers (objective) view, except in the case of the superstructure where Harris lumps etic and emic together. 
the infrastructure but in my reading economic factors are placed in the second system or what Harris calls "structure." Harris (1979: p. 57) continues by stating that the infrastructure "is the principle interface between [socio] culture and nature."

As noted above, Harris' second system he simply identifies as "structure" (Harris, 1979: p. 54). Like White, Harris places the structure as subject to the strong influence of the infrastructure. The structure is composed of the "Domestic Economy" (which includes family structure; domestic division of labor; domestic socialization, enculturation, and education; age and sex roles; and domestic discipline, hierarchies, sanction) and "Political Economy" (which includes political organization, factions, clubs, associations, corporation; division of labor, taxation, tribute; political socialization, enculturation, education; class, caste, urban, rural hierarchies; discipline, and police/military control; war) (Harris, 1979: pp. 51-54). These categories are not exhaustive as the structure is made-up of all human groups and organizations (Elwell, 2013: p. 3).

Under "superstructure" Harris includes symbols, myths, aesthetic; standards and philosophies; epistemologies, and ideologies; and magic, religion, and taboos. Again these categories are not exhaustive but exemplary. These three sociocultural systems make up the sociocultural structure as a whole with the infrastructure being the dominated causal system much the same as Marx and White suggest. These three sociocultural systems are proposed as largely explaining both complex behavior and thought like incest avoidance and the incest taboo.

\section{Sociocultural Evolution: The General Case}

Materialist-environmental theory includes explanations for both the general and specific evolution of human society. With general evolution the sociocultural system overall is examined, changing from a simple to a complex form. As noted above, Lenski (1970: p. 124) offers a well-established evolutionary typology of societies, modified from Goldschmidt's (1959: p. 194) classification scheme. This typology is constructed on the foundation of the subsistence technology in a society. Most of the societal categories in this scheme have simple and advanced forms. These include what Lenski calls "mainstream societies": simple and advanced hunting and gathering, simple and advanced horticulture, simple and advanced agrarian, and industrial society. Lenski also includes "hybrid" societies, again from simplest to advanced forms: fishing societies (roughly equivalent to simple and advanced horticulture), simple and advanced herding (roughly equivalent to simple horticulture and simple agrarian), and maritime societies (roughly equivalent to simple agrarian and advanced agrarian).

Harris (1977) gives a well described and reasoned account of general evolution beginning with Stone Age hunters and gathers from the Paleolithic ice age (about 30,000 B.C. to 10,000 B.C.). These people hunted and gathered for a wide range of flora and fauna but are best known for hunting a variety of large game species. Because of the globally cold temperatures, with a considerable amount 
of the planet's water frozen in the ice caps and glaciers, large expansions of grass land appeared as forests receded due to the lack of water. This vast expansion of grass lands was able to support large numbers of giant ungulates such as mammoths and mastodons, and in turn, these grass-eaters fed other large predatory species. This provided Paleolithic peoples with a plentiful high protein diet and animal product for tools, shelter and other necessities.

About 13,000 years ago the earth's climate began to warm. Released water from melting ice resulted in growing forests, rising seas and vanishing grasslands. Large species of grass-eaters, and the animals that fed on them, began to decline in numbers. This led to an intensification of hunting and the eventual extinction of giant fauna. As a result, hunters turned to smaller game. Relatively quickly they over hunted these smaller animals as it required many more animals to equal a giant animal kill. Under these circumstances people turned to more flora in their diet which resulted in greater fertility. With increasing population pressure, gathering gradually turned to cultivation and a change from high protein diets to high carbohydrate diets. This diet transformation led to a faster growing population as women became increasingly fertile on higher carbohydrate foods. In addition, the appearance of labor intensive agriculture encouraged large families and faster population growth. This growing population would be the main factor driving the evolution of human sociocultural systems.

During the Paleolithic ice age hunting and gathering people kept their populations under control (below the carrying capacity) through a number of methods. Infant mortality was as high as 50 percent. Female mortality was also high limiting the number of infants born. As humans evolved to an upright walking position a woman's birth canal became smaller. At the same time infants' heads were becoming larger. This difficulty in giving birth resulted in a higher mortality rate for infants and mothers. As noted, this was accompanied by a high protein low carbohydrate diet, which combined with extensive exercise from daily gathering activities kept women's body fat and stored nutrients low making pregnancies less frequent. Lactation also helped space pregnancies to two or more years as women on this diet and nursing an infant more slowly gained body fat and nutrients necessary for pregnancy. In times of scarcity, or when women already had a young infant to feed, female infanticide (probably the most common way of controlling population growth) or abortion were common. All of these practices and circumstances resulted in a stable population.

With the earth's warming climate and the disappearance of large fauna and the grasslands they fed on, and with increasing population pressure, humans were forced down a path to agriculture; plant food calories to a large degree replacing meat calories. As noted, this high carbohydrate diet and sedentary life lead to population pressure as women were gaining weight faster after each pregnancy, and being fertile each year, had more children. This situation created a critical problem because as the population began growing faster the amount of arable land on the planet was much more limited than hunting and gathering 
space. Eventually, population growth meant that moving to a new territory when the soil wore out (slash-and-burn agriculture) became increasingly difficult because of encroaching enemy neighbors. This entailed two things emerging at the same time. First, humans had to intensify their agricultural production, and second, they needed to fight over land with their enemy neighbors.

The intensification of agriculture meant a number of things: the development of better agricultural tools, the fertilization of the soil, the growing of those plants which produced the most calories and raising hybrids that produce more food, irrigation and terracing which allowed more land to come into cultivation, the production of plants that could be processed for storage, and the domestication of animals for food and for work. All of these things allowed societies to produce more food and attempt to keep up with a rapidly growing population.

Intensification also included warfare both within tribes and between tribes along with the stratification of society (Leavitt, 1977: pp. 49-58). Warfare began with raiding skirmishes mainly meant to keep enemy neighbors at bay but fairly quickly evolved into a conquest for land. As warfare evolved so did the viciousness of the fighting and the training of men to be fierce, aggressive and violent (Harris, 1974: pp. 61-107). Intensification of warfare also meant the increasing improvement of weapons and strategies.

Warfare, population growth and the increasing scarcity of arable land resulted in a competition initiating stratification, social inequality and differentiation. This warfare and inequality led to an inferior status for women. Warfare puts a premium on raising sons while making female infanticide more common. Although men had a higher status because of warfare, the resulting lower status of women actually protected them from being killed when enemy warriors overran a village. Because women were considered to be relatively harmless and weak, often being restricted from even handling weapons, they were more likely to be ignored in the fighting and less likely to be killed. Even though women were often considered valuable as war captives, even a few remaining women could, relatively quickly, and with only a few men, repopulate a defeated community. Likewise, because women were often the source of labor in early agricultural societies, they were more important than men for the recovery of a group. But even this value for women did not exceed the status acquired by warriors who were rewarded for risking their lives.

With continued population pressure advanced agricultural practices appeared, using the plow and draft animals. Because of a less labor intensive farming practice the population began shifting to towns and cities. As societies continued to evolve, stratification based on wealth and political power also increased and the society became more complex. Today the human population continues to grow and is not expected to level off until the mid- $21^{\text {st }}$ century. Thus warfare continues as does the intensification of technology.

The above outline of general evolution is brief and incomplete but should give the reader not only an idea of how general evolution proceeded but also an ex- 
ample of the power of environmental theory for explaining complex human behavior. ${ }^{3}$ In sum, with climate change humans were forced to change their subsistence activities from hunting and gathering to agriculture. This led to an increasingly rapid population growth, the intensification of technology and subsistence activities, warfare, and a more stratified and differentiated society. An increasingly complex society, driven by population pressure, eventually led to modern postindustrial societies which only recently produced a standard of living higher than that experienced by hunter gatherers.

\section{Sociocultural Evolution: A Specific Case of a Taboo}

Specific sociocultural evolution is concerned with the changes of particular societies, events and complex behaviors. ${ }^{4}$ As materialist-environmental explanations they are very powerful for understanding specific complex human behaviors. To demonstrate the efficacy of these explanations we will briefly examine the case of the Hindu sacred cow taboo (Harris, 1974: pp. 11-32; 1977: pp. 139-163).

India not uncommonly experiences droughts and crop failures. These droughts can sometimes last for years resulting in widespread starvation. Even under these extreme conditions farmers and their families will not slaughter their cows for food. While all peoples have food taboos, most would not conclude that this results from natural selection. Similarly, we will see that the incest taboo, like the cow taboo, is the result of practical everyday problems that are so serious that strong rules must apply to enhance the long run survival of the society.

Even though Hindu Indian society has a very strong taboo against eating cattle, especially the cow (they also intensely frown on eating other meats), there is no doubt that in the distant past they ate meat, including not only cattle, but pigs, water buffalo, chickens, elephants, and camels. In these times, (roughly prior to the first millennium) the average peasant farmer had a large enough farm to raise several kinds of livestock and supplement the animal's diets with the grain he raised. These animals provided meat for the farmer's family diet, beef being the most common and preferred.

As the population grew in this agricultural society the Indian population found their farms getting smaller with fewer animals being raised. It became more and more practical for farmers to eat their grain and vegetables rather than using their crop land to feed their animals. On the same land grain and vegetable calories were cheaper and more plentiful than meat calories. In the first millennium as the population grew the eating of meat gradually became regulated by ritual sacrifice, a practice not uncommon in agricultural societies. The priestly class of Brahmans and their secular elites, having more resources for raising animals, began to feed an area population with meat during certain sacrifice ri${ }^{3}$ For a more complete presentation of general evolution see Harris $(1974,1977)$ and Nolan and Lenski (2014).

${ }^{4}$ For examples of specific materialist-environmental explanations see Harris (1974); Diamond (1997, 2005) and Mann (2005, 2012). 
tuals and holy days. Such activity acted as a rationing scheme. Rather than eating meat when desired it was rationed by ritual and holy days making meat an ever rarer resource consumed more efficiently.

Harris (1977: p. 143) observes that "[A]fter 600 B.C. the Brahmans and their secular overlords found it increasingly difficult to satisfy the popular demand for animal flesh ... they were unable to maintain high rates of animal slaughter and bountiful redistribution..." This led to feasting being restricted to the elite. The peasant farmer who was gradually, over time, getting rid of his unnecessary stock found himself with two oxen for pulling his plow and a cow for producing more oxen.

Oxen and cows are absolutely necessary if Indian farming is to continue and the farmer and his family are to stay alive. In addition to the oxen produced by cows as traction animals, the farmer needs their cattle for fertilizer. Livestock produce about 3 million tons of dung each year about half is used for fertilizer. In addition, cattle manure is the common source of fuel in rural India. Harris (1974: pp. 18-19) notes, dung is "a superior cooking fuel... Most Indians dishes are prepared with clarified butter ... for which cow dung is the preferred source of heat since it burns with a clean, slow, long-lasting flame that doesn't scorch the food. This enables the Indian housewife to start cooking her meals and to leave them unattended for several hours while she takes care of the children, helps out in the fields or performs other chores."

Even though cows are not eaten, they are still an important source of protein producing milk, butter and cheese, which are commonly consumed at meals. In addition, cattle dung is mixed with water to making a paste that is used for floors and walls. When cattle die, they can also be a source of leather.

With the severe population pressure in India and the reduction of oxen and cows to the bare minimum, a strong rule-a sacred taboo fortified with religion-was necessary to preserve cows especially during periods of want and starvation. The Indian farmer who killed his cow for food finds that he had no source of traction animals for cultivation and no source of fuel and protein things absolutely necessary for survival on his farm. His only alternative was to sell his farm and move to a city where living conditions were very poor.

In American society we can find the early beginnings of a similar meat restriction. Currently, American farmers feed livestock $3 / 4$ of the food they raise. As land values rise, and farming and ranching become increasingly expensive, the cost is reflected in higher beef prices. This has resulted in Americans eating more chicken. But chickens also eat grains consumed by humans and their price is also rising. Vegetarianism has become more common, some going to the extreme of eating no animal products. Structurally and ideologically groups like PETA and the ASCPA are becoming more common and have been successful in improving the environmental conditions of captive animal species. Improved living conditions for animals also mean higher costs and prices. Some of these animal rights groups are forwarding the idea that eating meat is unhealthy and environmentally harmful. As the planet's population continues to grow we may 
very well see stronger negative attitudes regarding the eating of beef and other meats.

\section{The Incest Taboo: General Evolution and Survival Alliances}

If I have demonstrated the power of materialist-environmental accounts for explaining sociocultural phenomena then we may have more confidence in offering a similar explanation for the incest taboo. The incest taboo is an ideational phenomenon subject to the technological and social structural complexity of society (Leavitt, 1986: pp. 525-553; Leavitt, 1989: pp. 116-131). As such, we might expect the incest taboo to systematically change as the sociocultural system evolves. If the incest taboo follows a general evolutionary path, we can begin to conclude that it is not a fixed biological mechanism but a flexible sociocultural entity.

In 1978 Yehudi Cohen proposed three general evolutionary hypotheses that are related to the incest taboo. In the first hypothesis Cohen proposed that as the sociocultural system becomes more complex the degree of the relatives included in the taboo would contract. The second hypothesis states that as trade practices develop the extension of the incest taboo would shrink. In the third hypothesis Cohen purported that as the sociocultural systems evolve becoming more complex the severity of punishment for violating the incest taboo would lessen. In general, I (Leavitt, 1989: pp. 121-125) found empirical support for these three hypotheses.

The exception in the first hypothesis is with hunting and gathering societies. Whereas Cohen predicted that they would have the furthest extension of the taboo the results were mixed. Hunting and gathering societies with bilateral descent ${ }^{5}$ were the least extended with their incest taboo. What I suspect is that those hunting and gathering societies that are least developed (simple hunting and gathering) were bilateral. In this instance they practiced a band incest taboo where individuals were required to have sex and marry outside of their own band. This would tie bands together through marriage and sex making the acquisition of necessary resources easier to acquire. As hunting and gathering societies evolved becoming more complex (advanced hunting and gathering), they changed to unilineal descent ${ }^{6}$ perhaps because their mobility became more restricted by encroaching neighbors. Unilineal societies are organized around lineages or clans extending the incest taboo to distant relatives giving a band more access to scarce resources through a marriage and sex taboo.

Simple agricultural societies (horticultural societies) had even more extended unilineal kinship groups and incest taboos forcing their children to marry into other clans often in other territories. With the appearance of advanced agricul${ }^{5}$ With bilateral descent an individual traces their descent equally through both parents. This is a system common in modern industrial societies like American society.

${ }^{6}$ Tracing ones descent only through the father's patrilineal or mother's matrilineal line is unilineal descent. There are a few societies where an individual has dual memberships or belongs to two kinship groups. This does not include all of one's relatives, however. 
ture (agrarian societies) which had field cultivation using the plow and draft animals, kinship groups began to disappear leading back to bilateral descent in more modern societies. These agrarian societies developed trade institutions that replaced family alliances and the need for an extended incest taboo. Here again we see a flexible sociocultural trait, the incest taboo, subject to other sociocultural variables and to general societal evolution.

The important key to understanding the incest taboo lies in part with Cohen's second hypothesis on trade. As Leavitt (1989: p. 124) demonstrates, the extension of the incest taboo to distant relatives diminishes as the practice of trade institutionalizes in society. In the earliest societies (simple hunting and gathering), people were quite mobile finding most resources as they migrated. The need for trading in this case was limited to between individuals and bands, each band traveling through different territories and having access to different trade items. But as sociocultural systems increase in complexity, and become more restricted in their movements because of agriculture, a rule of exogamy and incest taboo required people to reach farther and farther out in society to find partners. This made the trade for scarce resources easier for all involved. Approaching strangers for the resources one needs is difficult and dangerous. Approaching people tied by marriage smooths the way to friendly relationships and trade. As sociocultural systems continue to become more complex specialized institutions of trade developed and the need for kin based trade becomes less important. In modern society the government and corporations (often working together) engage with other societies for needed resources and protect themselves with standing armies.

Hence, the incest taboo is an important rule in a complex set of rules, which insist that the young seek marriage and sex partners outside of the more immediate family so as to create strong alliances necessary for survival. As Tylor (1888: p. 245) argued, "[T]ribes must have had plainly before their minds the simple practical alternative between marrying out and being killed out." These alliances did not only insure trade, but also led to other alliances for economic, political and military purposes.

Cohen's third hypothesis proposed that as sociocultural systems evolve, the severity of punishment for the violation of the incest taboo would decline. In early societies violation of the incest taboo could lead to expulsion or death. Today the taboo is largely confined to the nuclear family, aunts and uncles, grandparents and sometimes first cousins. Except in the case of adult incest with children, incest is largely undetected and seldom punished when it occurs between adults. Cohen expected that the incest taboo would disappear and cited a case in Sweden where their highest court ruled that incest between adults was not the concern of the state.

\section{Summary and Conclusion}

For many years, but especially since the publication of Sociobiology by Edward 
O. Wilson (1975), Darwinian social scientists, many of whom are not social scientists and are thus unable to speak authoritatively about social science theory, have claimed with no direct evidence that the incest taboo and incest avoidance are products of natural selection process. Similar claims have been made about a wide variety of sociocultural traits including racial intelligence, warfare, the abilities of women, the abilities of various racial and ethnic minorities, territoriality, rape, sexual jealousy, crime, and beauty to name but a few. Although many natural selectionists have disavowed such views others hold stubbornly to these claims (see Wilson, 1975; Alcock, 2003).

For natural selectionists the incest taboo originated to prevent inbreeding because they assert that inbreeding is harmful to progeny. This assertion has been more recently revised to include only close inbreeding; that is, inbreeding within the immediate and nuclear family, because strong evidence demonstrates that more extended inbreeding is not only harmless but advantageous for preserving adaptive genomes. The allegation that close inbreeding is harmful has long been addressed and convincingly refuted with empirical evidence (see Shields, 1982; Leavitt, 2007: pp. 393-419; 2005: pp. 139-157). As summarized by Shields (1982: p. 196) "There is an alternative view of much of that evidence and additional evidence that is cited less often that flatly contradicts the view that inbreeding (or even incest) per se is maladaptive."

In an extensive review of studies on consanguineous mattings, Alvarez et al. (2011: pp. 21-40) found that first cousin marriages are quite common. "(I)t has been recently estimated that the consanguineous couples and their progeny suppose 10.4\% of the global population..." (Bittles \& Black, 2010; in Alvarez et al., 2011: pp. 21-22). "Marriage between first cousins...is considered the most prevalent consanguineous union in human populations. (I)t is possible to find certain populations with high incidence of uncle-niece unions" (Alvarez et al., 2011: p. 24). In a collection of studies, birth defects in the children of first cousins were found to range from $1.7 \%$ to $2.8 \%$ higher than those of the non-consanguineous population (Bennett et al., 2002; in Alvarez et al., 2011: p. 29). Even so, no incest avoidance mechanism has been selected and this inbreeding continues. As Alvarez et al. (2011: p. 40) conclude, "Inbreeding defined as the mating between relatives is a phenomenon that occurs in...many humans."

Of the two theories in competition here, materialist-environmental explanations are certainly the simpler ones. The factors concerned can be observed and measured providing, as Harris (1974: p. 11) observes, "practical and mundane" elements of human life, which can explain complex human behaviors. As argued above, the environment provides a powerful means for explaining even initially cryptic human behaviors like the sociocultural evolution of the incest taboo extension or even more mysteriously the Hindu sacred cow taboo. In both cases we can see that complex behavior is being explained by environmental circumstances. The incest taboo, a simple ban on sexual relations between certain de- 
grees of kin is as easily explained through a study of environmental factors.

\section{Conflicts of Interest}

The author declares no conflicts of interest regarding the publication of this paper.

\section{References}

Alcock, J. (2003). The Triumph of Sociobiology. New York: Oxford Univerand Genetic Disorder.

Alvarez, G., Quinteiro, C., \& Ceballos, F. C. (2011). Inbreeding and Genetic Disorder. In K. Ikehara (Ed.), Advances in the Study of Genetic Disorders (pp. 21-44). Rijeka: InTech. https://doi.org/10.5772/18373

Bennett, R. L., Motulsky, A. G., Bittles, A., Hudgins, L., \& Uhrich, S. (2002). Genetic Counseling and Screening of Consanguineous Couples and Their Offspring: Recommendation of the National Society of Genetic Counselors. Journal of Genetic Counseling, 11, 297-119. https://doi.org/10.1023/A:1014593404915

Bittles, A. H., \& Black, M. L. (2010). Consanguinity, Human Evolution, and Complex Diseases. Proceedings of the National Academy of Sciences, 107, 1779-1786. https://doi.org/10.1073/pnas.0906079106

Buzney, C., \& Marcoux, J. (2021). Cultural Materialism. https://anthropology.ua.edu/theory/cultural-materialism

Cohen, Y. (1978). The Disappearance of the Incest Taboo. Human Nature, 1, 72-78.

Denton, M. (1985). Evolution: A Theory in Crisis. Bethesda, MD: Adler \& Adler.

Diamond, J. (1997). Guns, Germs, and Steel. The Fates of Human Societies. New York: W.W. Norton \& Company.

Diamond, J. (2005). Collapse. How Societies Choose to Fail or Succeed. New York: Viking.

Elwell, F. W. (2013). Harris on the Universal Structure of Society. http://www.faculty.rsu.edu/users/f/felwell/www/Theorists/Essays/Harris1.htm

Goldschmidt, W. (1959). Man's Way: A Preface to the Understanding of Human Society. New York: Holt.

Harris, M. ([1968]2001). The Rise of Anthropological Theory. A History of Theories of Culture. New York: Altamira Press.

Harris, M. (1974). Cows, Pigs, Wars \& Witches. The Riddles of Culture. New York: Random House.

Harris, M. (1977). Cannibals and Kings. The Origins of Culture. New York: Random House.

Harris, M. (1979). Cultural Materialism: The Struggle for a Science of Culture. New York: Random House.

Leavitt, G. C. (1977). The Frequency of Warfare. An Evolutionary Perspective. Sociological Inquiry, 47, 49-58. https://doi.org/10.1111/j.1475-682X.1977.tb00778.x

Leavitt, G. C. (1986). Ideology and the Materialist Model of General Evolution: A Cross-Cultural Test of Subsystem Relationships. Social Forces, 65, 525-553. https://doi.org/10.1093/sf/65.2.525

Leavitt, G. C. (1989). Disappearance of the Incest Taboo: A Cross-Cultural Test of General Evolutionary Hypotheses. American Anthropologist, 91, 116-131.

https://doi.org/10.1525/aa.1989.91.1.02a00070 
Leavitt, G. C. (2005). Incest and Inbreeding Avoidance. A Critique of Darwinian Social Science. Lewiston, New York: The Edwin Mellen Press.

Leavitt, G. C. (2007). The Incest Taboo? A Reconsideration of Westermarck. Anthropological Theory, 7, 393-419. https://doi.org/10.1177/1463499607083427

Lenski, G. (1970). Human Societies. A Macrolevel Introduction to Sociology. New York: McGraw-Hill Book Company.

Mann, C. C. (2005). 1491. New Relations of the Americas before Columbus. New York: Alfred A. Knopf.

Mann, C. C. (2012). 1493: Uncovering the New World Columbus Created. New York: Vintage.

Marx, K. ([1867]1975). Capital. A Critique of Political Economy (Vol. 1). New York: International Press.

Nolan, P., \& Lenski, G. (2014). Human Societies: An Introduction to Macrosociology. New York: Oxford University Press.

Shields, W. (1982). Philopatry, Inbreeding, and the Evolution of Sex. Albany, NY: State University of New York Press.

Tylor, E. B. (1888). On a Method of Investigation the Development of Institutions; Applied to Laws of Marriage and Descent. Journal of the Royal Anthropological Institute, 18, 245-269. https://doi.org/10.2307/2842423

Westermarck, E. (1891). The History of Human Marriage. London: Macmillan.

White, L. A. ([1949]1969). The Science of Culture. A Study of Man and Civilization. New York: Farrar, Straus and Giroux.

Wilson, E. O. (1975). Sociobiology. The New Synthesis. Cambridge, MA: Belknap Press. 